\title{
Developing Secondary School Students' Foreign Language Speaking Skills in the Netherlands: A Design Research Study
}

\author{
Ann Kerbey ${ }^{1}$, Anssi Roiha ${ }^{2, *}$ \\ ${ }^{1}$ English Department, Faculty of Education, HU University of Applied Sciences Utrecht, the Netherlands \\ ${ }^{2}$ Department of Teacher Education, Faculty of Education, University of Turku, Finland
}

Received November 20, 2020; Revised December 15, 2020; Accepted January 28, 2021

\section{Cite This Paper in the following Citation Styles}

(a): [1] Ann Kerbey, Anssi Roiha, "Developing Secondary School Students' Foreign Language Speaking Skills in the Netherlands: A Design Research Study," Universal Journal of Educational Research, Vol. 9, No. 1, pp. 161 - 170, 2021. DOI: 10.13189/ujer.2021.090118.

(b): Ann Kerbey, Anssi Roiha (2021). Developing Secondary School Students' Foreign Language Speaking Skills in the Netherlands: A Design Research Study. Universal Journal of Educational Research, 9(1), 161 - 170. DOI: 10.13189/ujer.2021.090118.

Copyright $(2021$ by authors, all rights reserved. Authors agree that this article remains permanently open access under the terms of the Creative Commons Attribution License 4.0 International License

\begin{abstract}
The aim of this design research project was to investigate possible ways of developing foreign language (i.e. English) speaking skills of secondary school students who do not readily speak English in class. It was felt that an intervention was required to raise student-speaking skills in preparation for their oral exam. Empirical data were collected and a literature review was conducted in order to have a deeper understanding of the problem. The data collection methods of the study were questionnaires, interviews, lessons observations as well as a course book analysis. The data collected indicated that speaking production can be affected by a number of criteria such as anxiety, confidence, lack of vocabulary and/or practice. The data collection and the literature review informed the designed product (i.e. series of six lessons focusing on developing students' speaking skills). The product was trialled during May 2020 and both teachers and students were asked for their assessment of the product. The evaluation data were collected through interviews and questionnaires. The evaluation of the product showed that both teachers and students received the product positively and it was found to have had positive effect in changing students' perception of their speaking ability. The results of this study encourage teachers to deviate from textbooks that do not extensively focus on oral production and come up with alternative products to increase student-speaking time in foreign language education.
\end{abstract}

Keywords English as a Foreign Language, Speaking Skills, Confidence, Anxiety, Motivation, Design Research

\section{Introduction}

Speaking tends to be a skill that students find challenging and feel insecure about in foreign language learning $[1,2]$. At the same time, speaking is the area of language education that is usually considered the most important. This study focused on addressing students' speaking skills. The study can be labelled both an action research since the aim of the project was to develop the teaching practices in the school where author 1 was working as a teacher [3] as well as a design research since based on data collection and literature review, a product was designed and evaluated [4]. More specifically, this research endeavoured to investigate and address possible ways of developing and encouraging speaking skills of third-year HAVO (i.e. Hoger algemeen voortgezet onderwijs) students in the Netherlands. HAVO is a type of secondary education that has five grades (ages 12-17). After completing HAVO, students have access to polytechnic tertiary education. It was observed that third-year students do not readily speak English in class and their textbook does not provide enough speaking 
activities. It was felt that an intervention was required to raise student speaking skills in preparation for their oral exam. The initial situation led to the formation of the following overarching research question:

How can third-year HAVO students be supported and encouraged to develop their speaking skills?

\section{Data Collection and Analysis}

The data were collected in the spring of 2020 by author 1. Mixed methods were used to provide a more accurate picture of the problem experienced [5]. The quantitative data were analysed using descriptive statistics such as frequencies, means and standard deviations. The qualitative data were subjected to content analysis.

More specifically, the practical research involved the following five elements: 1) a questionnaire for the English department teachers $(\mathrm{n}=6), 2)$ two structured interviews conducted with pre-set questions for the two teachers that currently teach the third-year HAVO students, 3) English lesson observations, 4) a Likert scale questionnaire for the third-year HAVO students $(n=17)$ relating to their perception of their motivation, ability, anxiety and strategies in speaking English and 5) analysis of the book currently used for third-year HAVO students.

In the teacher questionnaire, the participants had to state which of the four skills (i.e. reading, writing, listening, speaking) they find students struggling with the most. Moreover, the questionnaire asked the participants to label which aspects contribute to the students' weakest skills (e.g. lack of motivation, high level of anxiety, lack of practice) on a scale from 1 to 5 . The teacher interviews, in turn, covered questions about the teachers' teaching practices with regard to speaking. Author 1 endeavoured to remain as neutral as possible during the interviews and not to influence the participants' answers. However, the interview questions naturally guided the teachers' answers to some extent. Similarly, despite the attempts to approach the data with an open mind, it is generally agreed that qualitative analysis always entails some level of subjectivity.

The student questionnaire consisted of 11 statements that were presented in a 5-point Likert scale and one open question related to individual student's choice concerning a potential topic for their speaking test. The 5-point Likert scale used allowed for a neutral answer and thus reduced response bias [6]. Some statements were reverse to provide what are referred to as 'speed bumps' to demand that respondents slow down and pay attention to what they are reading [6]. The scoring was from 1 to 5 for positive statement with 1 representing disagreement and 5 representing agreement. The reserved statements had 1 for agreement and 5 for disagreement. To limit the number of questions was a considered choice to ensure that answering would be more accurate as long questionnaires can be tiresome for students potentially leading to inaccurate data retrieval. The questionnaire was also written in Dutch to avoid any misunderstanding on the part of the participants [5]. Due to the COVID-19 virus, it was not possible for the student questionnaire to take place in the classroom. It is possible that data collection within the classroom environment would have delivered a larger number of participants than the 17 students who responded. The low response rate can be considered a limitation of the study.

A lot of measures were taken to ensure the participants' privacy. The student questionnaires were completed with students anonymously filling in their views; therefore, even the researchers could not connect the answers to individual students. The references to the teachers in the article are also anonymised (e.g. Teacher1). Moreover, the name of the school or even the city do not become evident in the research report.

\section{Results}

\section{The teachers' perspective}

Three out of the six respondents felt that speaking was an issue in general for students and the common themes that were attributed to this were: lack of vocabulary, student confidence and amount of practice. The teachers were also asked if there was an area underrepresented in their lessons to which four of the respondents replied speaking, as Teacherl expanded upon, 'This is a very pragmatic choice. The Dutch system requires that students read and listen well. Writing and speaking are not as important in the final exams', alluding to teacher choice influenced by external factors.

From observations of English lessons and interviews with the two teachers, it was obvious that students do not readily use English to communicate with the teachers or each other. Dutch is still the predominant language used by students despite the teachers' use of the target language. Teachers themselves are also aware of drawbacks that are associated with demanding that students speak English as Teacherl stated that it 'interrupts the tempo of the lesson and getting information across'. This indicates that the time pressure felt within the lesson does not actively encourage teachers to promote getting the students to use the target language, which in turn would affect student confidence in using the target language. In addition, it was mentioned that student reluctance was observed and attributed to a variety of reasons such as peer pressure, being laughed at, being scared what others will think and limited vocabulary, which again relates to the students' level of confidence. This is a known problem associated with speaking in foreign language lessons [7]. Teacher2 went further to say that during speaking exercises, 'students often speak Dutch and only speak English as the teacher is next to them', 
therefore, highlighting the point that the inclusion of speaking activities does not automatically result in students speaking in the target language.

Improvements that the school has implemented up until now are on a suggestion level for third-year students and require their ability to work independently. Third-year HAVO students have been advised to spend time listening and watching television programmes in order to pick up on phrases and then to try to integrate these into their speech. When asked how the teachers experienced using the exercises in the course book, Teacher1 said that they 'were too disruptive' and prefers to supplement their lessons with found activities from the Internet.

In response to what the school has found to be effective in encouraging speaking, both Teacher1 and Teacher2 reported that second-year students receive an assignment to make a vlog. The aim is to improve fluency and the students enjoy making it, however, Teacher1 said that students often struggle with being able to find the right vocabulary. Teacher 2 stated that the 'use of technology helps with motivation' and that students are more motivated when they know it will be for a grade.

\section{The students' perspective}

The results from the student questionnaire are visualised in Table 1. One of the results that stood out was about students valuing learning English (i.e. statement 1). The mean score for this statement was very high (i.e. 4.53), expressing a positive result. It also had the lowest standard deviation of 0.61 , indicating that the students were in accord with each other. The second highest value was the reversed statement 6 . This shows a positive result again (i.e. mean score 4.35) and a standard deviation of 1.13. Both of these statements are linked to motivation and show that students are motivated to learn English. However, a limitation of these results is that students that are not motivated might have chosen not to complete the questionnaire in the first place only showing information from the more engaged students and therefore a more positive viewpoint.

Another interesting result was for statement 2 and was related to students' confidence in speaking English. The mean score for this statement is just below the neutral mean score at 2.65 , with a standard deviation of 0.84 , suggesting that students do not feel confident in their ability to speak English.
Table 1. Results from the student questionnaire

\begin{tabular}{|l|c|c|c|}
\hline \multicolumn{1}{|c|}{ Statement } & N & M & SD \\
\hline $\begin{array}{l}\text { 1. I feel there is a lot of value in learning } \\
\text { English }\end{array}$ & 17 & 4,53 & 0,61 \\
\hline 2. I feel confident speaking English & 17 & 2,65 & 0,84 \\
\hline 3. I feel anxious speaking English & 17 & 3,06 & 1,30 \\
\hline $\begin{array}{l}\text { 4. I often struggle for the right words when } \\
\text { speaking English }\end{array}$ & 17 & 3,29 & 1,07 \\
\hline 5. I can't speak very good English & 17 & 3,18 & 1,58 \\
\hline $\begin{array}{l}\text { 6. I don't feel that there is any point in } \\
\text { learning English }\end{array}$ & 17 & 4,35 & 1,13 \\
\hline $\begin{array}{l}\text { 7. I feel very self- conscious when I am } \\
\text { speaking in English }\end{array}$ & 17 & 3,12 & 0,83 \\
\hline $\begin{array}{l}\text { 8. I can speak very good English } \\
\text { 9. I feel that I have a good vocabulary and } \\
\text { that helps me to speak English }\end{array}$ & 17 & 3,18 & 1,20 \\
\hline $\begin{array}{l}\text { 10. If I find that I can't think of the right } \\
\text { word I can describe it in other ways }\end{array}$ & 17 & 3,24 & 1,16 \\
\hline $\begin{array}{l}\text { 11. My pronunciation stops me from } \\
\text { speaking English }\end{array}$ & 17 & 2,88 & 1,23 \\
\hline
\end{tabular}

The statements that were reversed scored are coloured light grey.

The statement that produced the widest spread in results was statement 5. This reversed statement relates to how students see their own competency in their ability to speak English. The standard deviation of 1.58 highlights that student opinion was very split. More specifically 29.4 percent of students felt they had a low competency, 47 percent felt competent to a certain extent and 23.5 percent were neutral with regard to their competency to speak English. When compared to its paired positive statement (i.e. statement 8), there is a mismatch in results as no student expressed a positive belief in their ability to speak English.

When it comes to anxiety, it seems that the students had mixed feelings about the topic. That is, the mean scores for statements 3 and 7 were just above neutral, 3.06 and 3.12 respectively. Statement 3 has a standard deviation above 1 which indicates that there is some fluctuation among the students. The questionnaire also indicated that pronunciation is a factor in restricting students' speaking, which again links into anxiety and the fear of not being able to say words correctly.

In conclusion, the students' results summarise that students are motivated to learn English but are hesitant and do not feel confident in their ability to speak, with some expressing more anxiety than others. Based on the data collected, it appears that exercises that build their confidence and vocabulary, whilst lowering anxiety would feed into their feelings of competence and increase their motivation even more. 
As regards compensation strategies, the results highlight a mismatch with students feeling that they struggle for words but simultaneously feel that their vocabulary is good (see Figure 1). The students' confidence in their ability to work around this lack of vocabulary seems to be also strong.

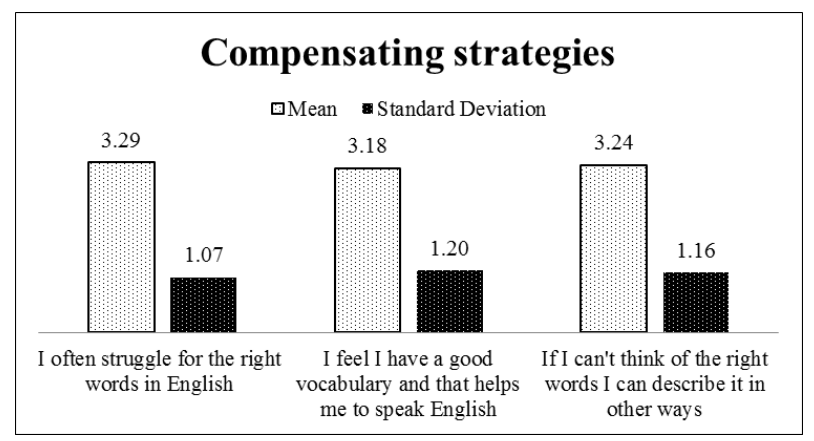

Figure 1. Students' use of compensating strategies

The results surrounding vocabulary overall were mixed. That is, the teachers' observation indicated that students lacked enough vocabulary to keep communication going, which could point to students not being aware of their limited vocabulary and therefore assessing their knowledge as high. What seems like a large vocabulary for them is viewed as small by a teacher's evaluation, indicating this difference of opinion between students and teachers.

\section{Course book}

Examination of the textbook used at the target school (i.e. All Right!) revealed one page per unit for speaking practice and one exercise in the students' workbook that is related to this page. Thus, speaking as a skill is largely underrepresented in the book, as well as listening, when the workbook on average has between 50 to 60 exercises per unit. The speaking exercises themselves focus on the students trying to either bridge an information gap or to express their own meaning, which is seen as being an essential part to language acquisition by cognitive engagement or the practice of 'learning by doing' [8].

\section{Theoretical Framework and Literature Review}

In order to design a functional product, literature on students' speaking was also consulted. In recent years, communicative language teaching (CLT) has become the umbrella term to describe numerous approaches that place communication, interaction and speaking in the forefront [9]. According to Brandl [8], the main principles of CLT focus on communication, task orientated activities, rich and meaningful input, collaboration, learning by doing, and focus on form and corrective feedback. In terms of educational approaches, CLIL (Content and Language
Integrated Learning) has been proven an effective vehicle with regard to language learning [10]. CLIL offers immersion in a language whilst teaching knowledge of subjects/topics that are not language related. This provides two possible channels of motivation for the students; one being content driven and the other language driven. CLIL's dual nature means that it promotes linguistic skills, due to the exposure and wider vocabulary that students encounter in context whilst also developing cognitive skills, the learning of additional material [11]. Whichever approach is used to teach a foreign language, the language offered to the learner needs to be at the appropriate level. Krashen [12] has described this as being interlanguage +1 , a term which he coined to express the idea of being just above the student's current level in order to push and develop their skills further. His concept bears similarities to Vygotsky's [13] zone of proximal development, which refers to the level slightly above the student's current level.

More specifically with regard to speaking, Schneider's [14] work gives a clear vision of an action that encourages speaking skills. He invited students to work in pairs and record their conversations as a strategy for developing speaking skills. Schneider [14] found that for pair taping to be successful, the pairs themselves needed to make regular recordings and they needed to be aware that the teacher was monitoring their output. The suggestion was to not listen to all the conversations but listen to snippets on a regular basis and give feedback, whilst also listening to whole conversations every once in a while. The students reported that speaking became easier and more pleasurable over the duration of their course, which Schneider [14] attributed to the frequent recording. Speaking was made more of a weekly ritual rather than a one-off occurrence. As students spoke more, there was an increase in their self-confidence and therefore an increase in student competency [14]. This corresponds with Deci and Ryan's [15] Self-Determination Theory, according to which confidence, competency and autonomy affect and influence the level and quality of motivation in learners. Therefore, an activity that promotes more confidence/competency in a student is likely to increase their level of motivation.

Collaboration in a foreign language classroom is not an entirely unproblematic method. Research into metacognitive skills in relation to individual or collaborative oral presentations has found that participants often feel that individual performance requires more metacognitive skills and thus assists and develops their language learning more than collaborative work [16]. However, collaboration lowers anxiety and students are able to recall information more readily as it is less to remember even if they feel it does not increase their language skills in the same manner [16]. It could also be that students are not necessarily aware of what they can learn from simply observing or listening to their peers.

In general, confidence and anxiety are common themes associated with speaking. Chou [17] has conducted a 
number of research projects on improving speaking levels by investigating research into lowering anxiety, focusing on the use of Cohen's [18] four strategies: retrieval, rehearsal, communication and cover. Chou's [17] research in this area highlighted that rehearsal provided the greatest gain in reducing student anxiety in speaking. Similarly, according to Staatsen and Heebing [19], confidence in speaking can only be achieved if speaking is practiced on a regular basis, which also agrees with Schneider's [14] findings and is also supported by Boonkit [20]. Students without adequate opportunities for speaking cannot be expected to successfully talk let alone hold a conversation. Courses or syllabuses should contain enough activities that allow students to practice their speaking production. Oradee's [21] research into developing speaking found that focusing on either discussion, problem-solving or role-play greatly improved the speaking levels of students. This indicates that the manner and the aim of the communication activities can influence student outcome. These activities can also help to lower student anxiety [20]. An additional way to lower anxiety is to have students perform in pairs rather than in front of the whole class [7]. This also has the increased benefit of the amount of time that all learners will spend talking.

To be able to communicate in the target language is the goal of most language education [7]. There is also often more motivation for speaking as a skill rather than any of the other skills. However, speaking is only possible with the ability to interpret what is being said or communicated, making speaking skills closely linked to listening skills [20]. By listening to authentic material, students hear the correct pronunciation, different accents of the target language speakers as well as chunks and phrases used in a natural context. Short documentaries are considered good resources for providing this type of information in a language lesson as they use the target language in a scripted form [22]. Soong's [22] study also discovered that 99 percent of the participants preferred watching a documentary rather than using a textbook. Film as a type of engagement therefore has the potential of creating motivation and interest, whilst also offering a wide choice of information (content) as the vehicle for language learning.

Vocabulary knowledge is an important part of speaking. In general, research into the effect of vocabulary on speaking performance has not been conducted on a large scale [23]. Oya, Manalo and Greenwood [24] concluded that vocabulary was an influencing factor in students' ability to speak. Similarly to this, Koizumi and In'nami's [25] studies suggest that vocabulary knowledge is central to speaking proficiency. Students who have more vocabulary seem to be more fluent speakers and knowing more vocabulary seems to boost speakers' confidence.

In relation to further addressing students' anxiety, students' self-perceived performance has a large role to play [26]. Students often see their own speaking level as being below where they actually are. One possible way of addressing student perception of their ability is through self-assessment. In order to foster motivation, it is important that learners understand what they can already do and also to set themselves goals of a realistic nature of what they wish to improve upon. Self-evaluation helps students to accept that making mistakes is a valid part of the learning process [11]. Self-assessment also makes it clear to the students what they are active with trying to learn/achieve. As De Saint Léger [27] suggests, in recent years the idea of self-assessment is thought to have a positive feedback into increasing motivation and developing traits that fall within the realm of self-regulated learning. Self-assessment is commonly achieved by giving students a rubric to assess the quality of the work they have produced against the expectations of the teacher [28]. This can promote students to understand their strengths and weaknesses, which in turn can help develop skills, as it will naturally provide a focus/goal for the student to work towards [29]. De Silva's [30] research into the effects of providing rubrics to promote writing and speaking skills showed that when students are provided with a rubric and given an explanation of how to use it effectively, it increased their speaking skills.

\section{The Product}

Based on the empirical data and literature review, a product was designed to develop foreign language speaking skills. The product is intended for use with the third-year HAVO classes and has been designed to meet the criteria established through the investigation of the data collected and the literature research conducted. Through using CLIL, the product is not dependent on a textbook but is an independent series of lessons that can be used as an intervention to increase student speaking. The goal of the product is to develop student speaking skills in preparation for their oral examination by expanding the students' current vocabulary, speaking skills and provide students with the necessary tools to converse and express their opinion in a topic that will become familiar to them by the end of the lesson series in line with CEFR goals [31].

The product consists of a series of six lessons surrounding the topic of 'Fake News', with complete lesson plans that serve as a teacher manual, two texts that will be used as the source material for the students' final oral exam and a rubric that the school wishes to use to assess the oral exams. The lesson series would be conducted over a period of three weeks with two online lessons per week and an oral exam taking place after the lesson series has been completed, also online.

In the oral exam, students will be expected to discuss the two texts for four to six minutes as a pair or six to nine minutes as a group of three. A group of three is permitted 
to take into account classes with an odd number of students. Students are free to indicate who they would like to work with for the pair assignments and oral exam. It is recommended that the same paring is used in the practice assignments and oral exam.

The lessons series have been designed to provide scaffolding for the students to guide them through the new topic. Scaffolding is seen as valid method providing students with support in learning new material by presenting the information in blocks that build upon each other [32]. Each lesson builds upon the previous one in terms of expanding on previous information, ideas and knowledge, increasing vocabulary and developing students' speaking skills.

The final activity in every lesson is a speaking activity and students are provided with a speaking rubric to assess their current level. The speaking activities are guided and as the student progresses through the lesson series the guidance decreases making the student a more independent speaker in preparation for the oral exam. This is done in order to prepare the student to be able to analyse the final texts and think of appropriate questions or conversation starters they could use with their speaking partner, making the final activity free production and authentic in its communication [8].

The provision of a rubric is linked to the theory that self-assessment is a valid method to improve speaking levels as it encourages students to set goals to improve their speaking. Students are asked to work on what they believe their two weakest areas are and therefore making the goals attainable. Students are asked to complete the rubric after each recording so that they can chart their improvement. For example, in the first recording, a student might notice that they say 'um' repeatedly. Having become aware of this when they come to make the next recording, they are able to reduce the number of times this happens because they are more conscious. Continual corrective feedback from the teacher can be seen as affecting student confidence and self-assessment provides students with tool to develop themselves [11].

The input material for the lessons is authentic material that has been graded to the students' level when required. Material for the lessons is a mixture of reading texts and listening/watching activities. The reading texts are presented by the teacher to practice developing students' reading strategies. The listening/watching materials are authentic and will help students develop their listening skills and through that their pronunciation skills.

\section{Evaluation of the Product}

The product was tested in two out of the three third-year HAVO classes at the target school in May 2020. The product consisted of six lessons given online due to social distancing rules as a result of COVID-19. The first two lessons were conducted and feedback was asked for from the teachers regarding the content, instructions of the product so that improvements could be made before the remaining lessons were given. The response was that the structure was clear and easy to follow and that the self-assessment of students was considered valuable. It was commented on that the use of articles chosen reflected current topics that also linked into the idea of 'Fake news' which was seen as a real and tangible topic for the students. It was also expressed that the input source for the lessons focusing on developing/practicing reading strategies was a positive aspect that would also help the students in their reading tests, giving students additional practice.

The research question to further evaluate the product was: To what extent did the 'Fake News' lesson series support, develop and encourage third-year students in their speaking abilities?

\section{Data collection}

The data discussed in this evaluation report were collected through qualitative and quantitative methods. The qualitative data consist of two structured interviews with two members of staff. These interviews were conducted via Google Meet and Whatsapp video call. The quantitative data were retrieved from two surveys administrated to the two classes that completed the lesson series. The survey results were collected by using a 5-point Likert scale given through Google Forms. One of the student surveys provided students with the option to leave additional feedback related to the course, which was treated as qualitative data. The quantitative data were analysed using descriptive statistics and the qualitative data relying on content analysis.

The student surveys were completed after the students had had their speaking test but had not received their result. This was done in order not to influence the students' response to the questions, as a positive result might have influenced the students to score both surveys higher than they would have otherwise and vice versa with a negative result. The students were asked to complete the same survey again that they had been given at the start of the research project to examine whether the students' perception of their speaking ability had changed. One limitation attached to these results was that only 17 students filled in the survey in the first stage whereas the two end evaluation surveys were filled in by 38 and 36 students respectively. Due to the possible outcome of more students completing the second survey than had previously taken part in the initial data retrieval, additional questions relating to ability, confidence and vocabulary were added into the survey that focused on how the students had experienced the lesson series. The combination of these results will be used to answer the research question of the evaluation phase. 


\section{Results}

In general, the teacher feedback was that the product met the requirements of the assignment to develop HAVO 3 students' speaking abilities. The choice of topic was seen as relevant to teenagers and as encouraging the development of critical thinking. The lesson series was considered a useable product at the time but remarks were made as to whether some of the materials would need to be updated in the years to come. Another recommendation was that the vocabulary could be introduced after the text/film to encourage a top-down approach instead of the bottom-up approach that was currently in the lesson plans. Additionally, it was suggested that the speaking activities could be improved by treating them more as a mini project and providing a more elaborate context for the conversation. The teacher that made these suggestions said that the top-down approach and context for the speaking were also a personal choice of how they prefer to teach. The final suggestion was to use a platform to keep all the information for students in one place in order to make it more user friendly. In terms of students' performance, of the 50 students having done the speaking test after following the product, there were three failing grades.

The evaluation results showed a positive change in student perception. Table 2 juxtaposes the means and standard deviations of the same survey conducted before the product $(\mathrm{n}=17)$ and after using it $(\mathrm{n}=38)$. The biggest increase is in response to the statement I feel confident in speaking English. This indicates that students feel slightly more confident after the series of lessons than before, although the overall score is just below neutral at 2.84 . Figure 2 shows the overall distribution of that statement.

When looking only at the evaluation survey $(n=38)$, the result with the largest standard deviation is for the statement I feel anxious speaking English. Although showing a spread of results, this score indicates that less students are feeling anxious as this statement is reversed scored and shows higher result of 3.63 when compared to the original result of 3.06 .

If comparing the scores from the initial survey to the evaluation survey, it could be concluded that the students are feeling more secure in their vocabulary (statement 10) and that they are feeling less anxious (statement 3 ). Therefore, it seems that the product has reduced the anxiety of students to speak English to some extent.

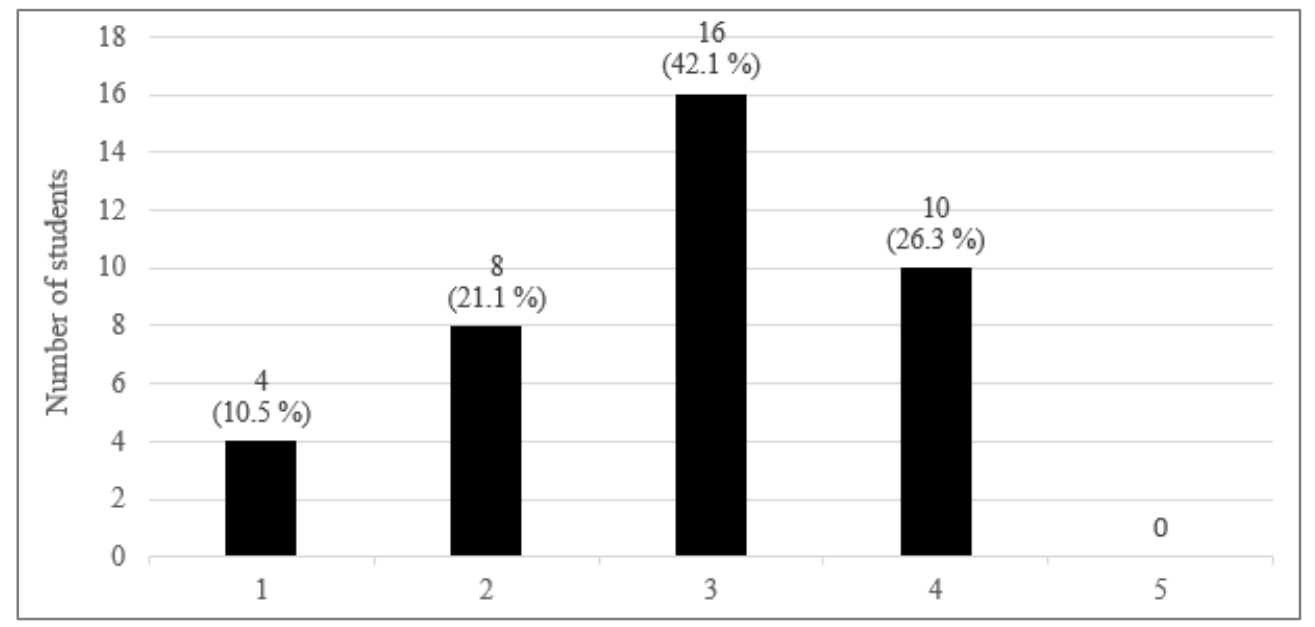

Figure 2. Students' responses to the statement 'I feel confident speaking English'

Table 2. Comparing questionnaire results from the first and second time of the same questionnaire being given

\begin{tabular}{|c|c|c|c|c|c|}
\hline & Statements & $\begin{array}{c}\text { Mean 1st } Q \\
n=17\end{array}$ & SD & $\begin{array}{c}\text { Mean 2nd Q } \\
n=38\end{array}$ & SD \\
\hline 1. & I feel there is a lot of value in learning English & 4,53 & 0,61 & 4,34 & 0,90 \\
\hline 2. & I feel confident speaking English & 2,65 & 0,84 & 2,84 & 0,93 \\
\hline 3. & I feel anxious speaking English & 3,06 & 1,30 & 3,63 & 1,16 \\
\hline 4. & I often struggle for the right words when speaking English & 3,29 & 1,07 & 3,13 & 0,98 \\
\hline 5. & I can't speak very good English & 3,18 & 1,58 & 3,05 & 1,07 \\
\hline 6. & I don't feel that there is any point in learning English & 4,35 & 1,13 & 4,53 & 1,04 \\
\hline 7. & I feel very self- conscious when I am speaking in English & 3,12 & 0,83 & 2,89 & 0,93 \\
\hline 8. & I can speak very good English & 2,59 & 1,09 & 2,84 & 0,93 \\
\hline 9. & I feel that I have a good vocabulary and that helps me to speak English & 3,18 & 1,20 & 3,03 & 0,93 \\
\hline & If I find that I can't think of the right word I can describe it in other ways & 3,24 & 1,16 & 3,58 & 0,99 \\
\hline 11. & My pronunciation stops me from speaking English & 2,88 & 1,23 & 2,92 & 0,96 \\
\hline
\end{tabular}

The statements that are coloured light grey are reversed scored. 
Table 3. Students' evaluation of the course

\begin{tabular}{|c|c|c|c|c|c|}
\hline Statements & $\mathbf{N}$ & Mean & SD & $\begin{array}{c}\text { Related } \\
\text { to }\end{array}$ & $\begin{array}{c}\text { Related to } \\
\text { student }\end{array}$ \\
\hline I found the lesson on 'Fake News' easy to follow & 36 & 3,78 & 0,92 & & \\
\hline $\begin{array}{l}\text { 2. I feel more confident in my speaking abilities since following the fake news } \\
\text { lessons }\end{array}$ & 36 & 2,92 & 0,92 & & \\
\hline I did not understand what I needed to do for the fake news lessons & 36 & 3,81 & 0,81 & & \\
\hline 4. I enjoyed the speaking exercises & 36 & 2,81 & 1,17 & & \\
\hline I did not complete all the exercises because I found them too difficult & 36 & 4,22 & 0,89 & & \\
\hline $\begin{array}{l}\text { 6. I felt that the self-assessment rubric helped me to develop my own speaking } \\
\text { skills }\end{array}$ & 36 & 2,28 & 1,17 & & \\
\hline 7. I did not complete all the exercises because I found them too boring & 36 & 4,08 & 0,92 & & \\
\hline 8. I enjoyed learning how to identify fake news & 36 & 2,97 & 1,14 & & \\
\hline $\begin{array}{l}\text { 9. I did not feel that the self-assessment rubric helped me to develop my } \\
\text { speaking skills }\end{array}$ & 36 & 2,44 & 1,04 & & \\
\hline 10. I feel more confident in my ability to hold a conversation & 36 & 3,06 & 1,15 & & \\
\hline 11. I feel that the fake news series did not prepare me for my speaking test & 36 & 3,67 & 1,18 & & \\
\hline 12. I found the exercises too easy and not challenging enough & 36 & 3,97 & 1,04 & & \\
\hline 13. I did not learn anything as I already knew how to identify fake news & 36 & 3,75 & 1,36 & & \\
\hline 14. The feedback that I got helped me to develop my speaking skills & 36 & 3,22 & 0,97 & & \\
\hline 15. I feel that the lessons prepared me for my speaking test & 36 & 3,42 & 1,16 & & \\
\hline 16. I feel that I know more vocabulary as a result of the lessons & 36 & 2,94 & 1,13 & & \\
\hline 17. I feel I have improved in my speaking skills & 36 & 3,28 & 1,22 & & \\
\hline 18. I did not complete all the exercises because I found them too difficult & 36 & 4,22 & 0,71 & & \\
\hline 19. I felt there were too many lessons and a few less would also have been fine & 36 & 3,47 & 1,12 & & \\
\hline
\end{tabular}

The statements that are reversed scored are coloured in light grey and the statements in dark grey were a repeat.

The second survey in the evaluation phase was related to how the students $(n=36)$ experienced the product but also contained statements that touch upon aspect of confidence, ability and vocabulary as a means of gaining additional information to compare to the results above (see Table 3). The two results that relate to how the students viewed their own ability that have a standard deviation under 1 are statements 14 , The feedback that I got helped me to develop my speaking skills (mean score 3.22) and statement 2, I feel more confident in my speaking abilities after following the fake news lessons (mean score 2.92). It is worth noting that the results from the first evaluation survey with 38 respondents show a clearer indication that students felt more capable after the series of lessons. The two results in the second evaluation survey showing the lowest scores are related to using the self-assessment rubric, which indicate that, although it is a concept based on theory, the students did not personally feel that it helped them develop their speaking skills.

In evaluating the course, the highest scoring statements were the reversed statements 5 and 18, I did not complete all the exercises as I found them too difficult. The next highest score was for reversed statement 7, I did not complete all the exercises as I found them too boring, which implies that the topics were of interest to the students. This result is then closely followed by statement
12, I found the exercises too easy and not challenging enough, which has a high mean score of 3.97 and is also a reversed statement. This indicates that the level of the lessons was pitched correctly for the students. Statement 13, I did not learn anything as I already knew how to identify fake news (mean score 3.75) and statement 11, I feel that the fake news series did not prepare me for my speaking test (mean score 3.67) which were also reversed scores show a positive score from the students. Statements 1 and 3, which are the reversed pair of each other show that the lessons and the aims of the lessons had been clear to the students as the mean scores were very similar with 3.78 and 3.81 respectively. These answers in combination express that the students had a positive experience of the lesson material. The qualitative data in the questionnaire indicate that the main student feedback was more variety in speaking exercises and that fewer lessons would have also been fine.

\section{Conclusions}

This research aimed at influencing third-year HAVO students' speaking skills. Based on the evaluation, it can be concluded that the product achieved the main aim that was intended; to provide a product that would stimulate 
speaking, increase confidence, lower anxiety and broaden third-year HAVO students' vocabulary. However, the inclusion of a self-assessment rubric did not produce the desired effect of further reducing anxiety or promoting confidence and the students did not view it as assisting them. This should be an area for further investigation as the students might have needed further instruction or a simpler rubric in order to access this tool. The product should be adapted to include some of the suggestions mentioned by the teachers at the target school for the speaking activities as the student qualitative feedback echoed that the exercises all felt the same. Also, it may be worth to consider reducing the lesson series in response to the student feedback. One area of weakness was the lack of differentiation in the input available to students. All students used the same source material and for those that exhibit stronger skills, it would have been of benefit to push them further to truly develop their capabilities. The above points should be factored in when designing future products of similar nature. Overall, regardless of its limitations, the product seemed to fulfil its primary purpose to positively affect the students' speaking skills. The results of this study have implications for language teachers and learning material designers. The study encourages teachers to deviate from the ready-made materials that do not focus enough on speaking and come up with alternative products to practice students' oral skills while considering their affective features. Oral skills should be given priority in learning materials and course books should have more speaking activities in them. Moreover, this study suggests that language education should include more exercises that build students' vocabulary as this may prompt them to speak more in class.

\section{REFERENCES}

[1] Ansari, M. S., "Speaking anxiety in ESL/EFL classrooms: A holistic approach and practical study," International Journal of Education Investigation, vol. 2, no. 4, pp. 38-46, 2015.

[2] Pihko, M.-K., "Minä, koulu ja englanti. Vertaileva tutkimus englanninkielisen sisällönopetuksen ja perinteisen englannin opetuksen affektiivisista tuloksista [Me, school and English. A comparative study of the affective outcomes of English teaching in content and language integrated (CLIL) classes and in traditional foreign language classes]", University of Jyväskylä, 2007.

[3] Sagor, R., "Guiding school improvement with action research", Alexandria, VA: ASCD, 2000.

[4] van den Akker, J., Gravemeijer, K., McKenney, S., Nieveen, N., "Introducing educational design research", In J. van den Akker, K. Gravemeijer, S. McKenney, N. Nieveen (Eds.), Educational design research, 2006, pp. 3-7. London: Routledge.
[5] Wilson, E., "Data collection", In E. Wilson (Ed.), School-based research. A guide for education students, 3rd ed, 2017, pp. 175-201. London: SAGE.

[6] Croasmun, J. T., Ostrom. L., "Using Likert-type scales in the social sciences" Journal of Adult Education, vol, 40, no. 1, pp. 19-22, 2011.

[7] Ur, P., "A course in English language teaching", 2nd ed, Cambridge: Cambridge University Press, 2012.

[8] Brandl, K., "Communicative language teaching in action: Putting principles to work", Upper Saddle River: Pearson Prentice Hall, 2008.

[9] Richards, J. C., "Communicative language teaching today", Cambridge: Cambridge University Press, 2006.

[10] Dalton-Puffer, C., "Content-and-language integrated learning: From practice to principles?", Annual Review of Applied Linguistics, vol. 30, pp. 182-204, 2011.

[11] Coyle, D., Hood, P., Marsh, D., "CLIL: Content and language integrated learning", Cambridge: Cambridge University Press, 2010.

[12] Krashen, S. D., "The input hypothesis: Issues and implications", London: Longman, 1986.

[13] Vygotsky, L. S., "Mind in society: The development of higher psychological processes", Translated and edited by M. Cole, V. John-Steiner, S. Scribner, E. Souberman, Cambridge: Harvard University Press, 1978.

[14] Schneider, P. H., "Using pair taping", The Internet TESL Journal, 1997. Retrieved from http://iteslj.org/Techniques/S chneider-PairTaping.html

[15] Deci, E., Ryan, R., "Self-determination theory and the facilitation of intrinsic motivation, social development, and well-being", American Psychologist, vol. 55, no. 1, pp. 6878,2000

[16] Chou, M., "The influence of learner strategies on oral presentations: A comparison between group and individual performance", English for Specific Purposes, vol. 30, no. 4, pp. 272-285, 2011.

[17] Chou, M., "Speaking anxiety and strategy use for learning English as a foreign language in full and partial English-medium instruction contexts", TESOL Quarterly, vol. 52, no. 3, pp. 611-633, 2018.

[18] Cohen, A. D., "Focus on language learners: Styles, strategies and motivation", In N. Schmitt (Ed.), An introduction to applied linguistics, 2010, pp. 161-178. London: Hodder Education.

[19] Staatsen, F., Heebing, S., "Moderne vreemde talen in de onderbouw [Modern foreign languages in the lower grades]", Bussum: Coutinho, 2015.

[20] Boonkit, K., "Enhancing the development of speaking skills for non-native speakers of English", Procedia - Social and Behavioural Sciences, vol. 2, no. 2, pp. 1305-1309, 2010.

[21] Oradee, T., "Developing speaking skills using three communicative activities (discussion, problem-solving, and role-playing)", International Journal of Social Science and Humanity, vol. 2, no. 6, pp. 533-535, 2012. 
[22] Soong, D., "Using documentaries in oral interpretation class. What is the appropriate length?", International Journal of Applied Linguistics \& English Literature, vol. 1, no. 6, pp. 131-141, 2012.

[23] Koizumi, R., "Relationships between productive vocabulary knowledge and speaking performance of Japanese learners of English at the novice level", Ph.D. diss., University of Tsukuba, 2005.

[24] Oya, T., Manalo, E., Greenwood, J., “The influence of language contact and vocabulary knowledge of speaking performance of Japanese students of English", The Open Applied Linguistics Journal, vol. 2, pp. 11-21, 2009.

[25] Koizumi, R., In'nami, Y., "Vocabulary knowledge and speaking proficiency among second language learners from novice to intermediate levels", Journal of Language Teaching and Research, vol. 4, no. 5, pp. 900-913, 2013.

[26] Zhang, X., "Foreign language anxiety and foreign language performance: A meta-analysis", The Modern Language Journal, vol. 103, no. 4, pp. 763-781, 2019.
[27] De Saint Léger, D., "Self-assessment of speaking skills and participation in a foreign language class", Foreign Language Annals, vol. 42, no. 1, pp. 158-178, 2009.

[28] Andrade, H., Valtcheva, A., "Promoting learning and achievement through self-assessment", Theory Into Practice, vol. 48, no. 1, pp. 12-19, 2009.

[29] DiBenedetto, K. M., "Self-regulation in secondary classrooms: Theoretical and research applications to learning and performance“, In K. M. DiBenedetto (Ed.), Connecting self-regulated learning and performance with instruction across high school content areas, 2018, pp. 3-23. Cham: Springer.

[30] De Silva, R., "Rubrics for assessment: Their effects on ESL students' authentic task performance", Center for English language communication 4th symposium proceedings, 2014.

[31] Council of Europe, "The CEFR levels",https://www.coe.int /en/web/common-european-framework-reference-languages /level-descriptions (accessed Nov. 21, 2020).

[32] Rosenshine, B., "Principles of instruction", Belgium: The International Academy of Education (IAE), 2010. 